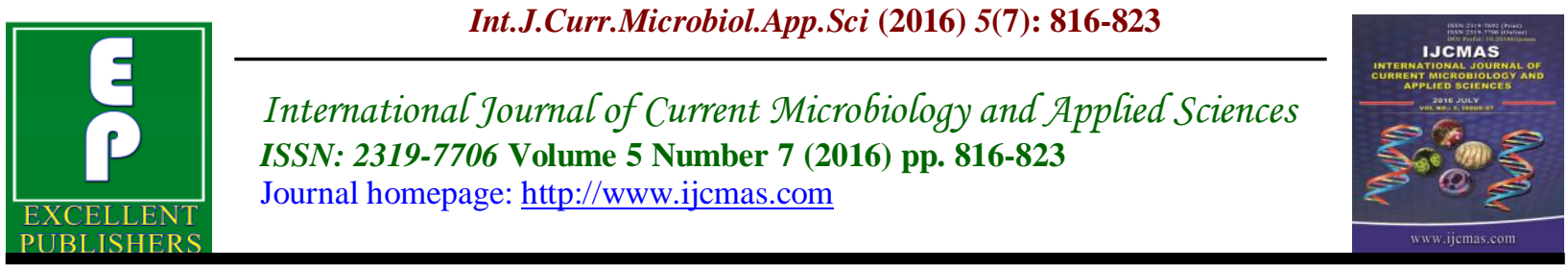

Original Research Article

http://dx.doi.org/10.20546/ijcmas.2016.507.094

\title{
Production of Short Chain Length Polyhydroxyalkanoates by Bacillus megaterium PHB29 from Starch Feed Stock
}

\author{
Balakrishna Pillai Aneesh, Jaya Kumar Arjun, Thulasi Kavitha and \\ Kumarapillai Harikrishnan*
}

\begin{abstract}
Environmental Biology Laboratory, Rajiv Gandhi Centre for Biotechnology, Poojappura Thiruvananthapuram-14, Kerala, India

*Corresponding author
\end{abstract}

Keywords

Poly-3-

hydroxybutyrate,

Bacillus

megaterium,

Amylase,

Starch, 1H NMR.

\section{Article Info}

Accepted:

25June 2016

Available Online:

10 July 2016

\section{A B S T R A C T}

Polyhydroxyalkanoates (PHAs) are accumulated in bacteria as an energy reserve and have attracted great scientific interest as a biodegradable, biocompatible alternative to conventional plastics. The study is focused on polyhydroxybutyrate (PHB) accumulation by an environmental bacterial isolate Bacillus megaterium PHB29 using starch as carbon feedstock. PHB accumulation in the isolate was visualized by staining techniques using Sudan Black B and Nile Red dyes. The biomass production as well as PHA accumulation in PHB29 was tested with starch as carbon source at different temperatures and found yielding $3.07 \mathrm{~g} / \mathrm{L}$ cell dry mass with $73.46 \%(\mathrm{w} / \mathrm{w})$ PHA accumulation at an optimum temperature $34^{\circ} \mathrm{C}$. The extracted polymer was subjected to ${ }^{1} \mathrm{H}$ NMR analysis and the spectrum showed signals for a methine group (-CH-), a methylene group $\left(-\mathrm{CH}_{2}-\right)$ and a methyl group $\left(-\mathrm{CH}_{3}\right)$ proving the polymer as poly-3-hydroxybutyrate $(\mathrm{PHB})$. The ratio of starch to PHB conversion of this isolate was found to be better than other reported strains of Bacillus megaterium as well as other species among the genus Bacillus.

\section{Introduction}

Polyhydroxyalkanoates (PHAs) are polyoxoesters of R-hydroxyalkanoic acid monomers accumulated in bacterial cytoplasm as granules when carbon sources are available in excess and other nutrients such as nitrogen and phosphorus are limited in their surroundings (Dawes and Senior, 1972; Lee et al., 1999). They act as carbonenergy reserves and also as electron sinks, which enhance the fitness of the bacteria and help in maintaining the redox balance
(López et al., 1995; Madison and Huisman 1999; Ruiz et al., 2006). These materials are biocompatible, non-toxic and considered as alternatives for conventional petroleum derived plastics (Chen, 2010). Depending on the bacterial strains, growth substrates and incubation conditions, the monomer composition of the accumulated polymer may vary and as a result, the properties of PHAs range from thermoplastics to elastomers (Braunegg et 
al., 1998; Keshavarz and Roy, 2010). The main attraction of PHAs is that, they are entirely degraded to carbon dioxide and water through natural microbial process. Consequently, their production, use and degradation never affect the environment adversely (Braunegg et al., 1998).

Most PHAs have been produced by prokaryotic microorganisms, including bacteria, cyanobacteria and archaea (Panda et al., 2005; Quillaguaman et al., 2005; Leong et al., 2014). Bacteria coming under the genera Bacillus are well known for their ability to accumulate poly-3hydroxybutyrate (PHB) which is the most common and simplest form of PHA with 3hydroxybutyrate $\left(\mathrm{C}_{4}\right)$ monomers. This class of short-chain-length (SCL) PHA is the first discovered and the most extensively studied biopolymer (Labużek and Radecka 2001; Shamala et al., 2003; Singh et al., 2009; Mizuno et al., 2010).

Even if polyhydroxyalkanoates have ideal properties as a substitute to environment polluting petroleum derived plastics, their applicability is limited due to their high cost of production. The cost of raw materials contributes a significant share to the manufacturing cost of PHA. In this scenario, researches have been focusing on reducing the production cost by replacing the expensive substrates with renewable cheap raw materials (Du et al., 2012). For industrial production of PHAs, starch may be a suitable cost effective alternative carbon source as it can be generated from various agricultural wastes (Chien and Ho 2008).

In this study, we used a starch utilizing bacteria isolated from the environment for analyzing its PHA accumulating property in a medium containing starch as carbon feed stock and observed simultaneous saccharification and fermentation with high polymer yield.

\section{Materials and Methods}

\section{Bacterial strain}

The bacterium used in this study, Bacillus megaterium PHB29 was isolated from forest soil collected from Western Ghats region, Thiruvananthapuram District and was previously reported for its Lasparaginase production (Arjun et al., 2015).

\section{Visualization of PHA accumulation}

Sudan Black $B$ staining: $1 \mu \mathrm{L}$ of the overnight bacterial culture was spotted on half strength nutrient agar (Himedia Laboratories Pvt. Ltd, Mumbai, India) plate supplemented with $2 \%$ glucose. After $48 \mathrm{~h}$ of incubation at room temperature, the plate was flooded with $0.05 \%$ solution of Sudan Black B in ethanol and kept undisturbed for $30 \mathrm{~min}$. The excess stain was washed out by sterile saline and observed the change in colony colour (Liu et al., 1998).

$10 \mu \mathrm{L}$ of $48 \mathrm{~h}$ old bacterial culture grown in half strength nutrient broth (Himedia Laboratories) supplemented with $2 \%$ glucose was made into a smear on a microscopic slide and stained with Sudan Black B (Murray et al., 1994). The smear was observed under 100X oil immersion objective lens of light microscope to visualize the polymer granules.

Nile Red staining: Cells from $1 \mathrm{~mL}$ of bacterial culture were harvested by centrifugation at $5000 \mathrm{xg}$, for $3 \mathrm{~min}$, washed with $0.1 \mathrm{M}$ phosphate buffered saline (PBS) and fixed in $20 \%$ formaldehyde solution. 1 $\mathrm{mL}$ of the cell suspension was mixed with $100 \mu \mathrm{L}$ of Nile red solution $(1 \mu \mathrm{g} / \mathrm{mL}$ in 
acetone) for $10 \min .10 \mu \mathrm{L}$ of bacterial cell suspension was taken on a glass slide and was covered by a cover slip (Greenspan et al., 1985; Jendrossek et al., 2007). The cells were imaged on a Nikon A1R-Si laser scanning confocal spectral microscope with 50X magnification at an excitation of 561 $\mathrm{nm}$.

\section{PHA production from starch}

The isolate was inoculated in $1000 \mathrm{~mL}$ basal medium (1.5 $\mathrm{g}$ of peptone, $1.5 \mathrm{~g}$ of yeast extract, $1 \mathrm{~g}$ of $\mathrm{Na}_{2} \mathrm{HPO}_{4}$ and $0.2 \mathrm{~g}$ of $\mathrm{MgSO}_{4} .7 \mathrm{H}_{2} \mathrm{O}$ per liter) with $20 \mathrm{~g} / \mathrm{L}$ of soluble starch (Himedia Laboratories) at $\mathrm{pH}$ 7.2 and incubated at different temperature conditions $\left(3^{\circ} \mathrm{C}\right.$ intervals between $28^{\circ} \mathrm{C}$ and $40^{\circ} \mathrm{C}$ ) for $48 \mathrm{~h}$. The experiments were done in triplicate and the cells harvested were washed with sterile normal saline. The biomass obtained was lyophilized and measured the cell dry mass (CDM). The polymer was extracted from dried biomass according to Shi et al., (1997) with slight modification. The cell mass was dispersed in $20 \mathrm{~mL}$ of sodium hypochlorite solution (available chlorine $5 \% \mathrm{w} / \mathrm{v}$ ) and incubated at $45^{\circ} \mathrm{C}$ for $1 \mathrm{~h}$. The lysate was pelleted at $8000 x g$ for 2 min and washed successively with $20 \mathrm{~mL}$ of sterile distilled water, acetone and absolute ethanol. The polymer obtained was dissolved in $20 \mathrm{~mL}$ of boiling chloroform and transferred to a clean glass Petri plate to evaporate the solvent. The polymer film obtained was weighed and estimated the yield in percentage $(\mathrm{w} / \mathrm{w})$.

\section{Identification of the polymer}

The proton Nuclear Magnetic Resonance Spectroscopy ( ${ }^{1} \mathrm{H}$ NMR) of the polymer was done after suspending the polymer in high purity deuterochloroform $\left(\mathrm{CDCl}_{3}\right) .{ }^{1} \mathrm{H}$ NMR spectra of the polymer were recorded at $500 \mathrm{MHz}$ and magnetic field strength of

\author{
$11.7 \mathrm{~T}$ in BrukerAvance ${ }^{\mathrm{II}} 500$ NMR \\ spectrometer (Bruker Corporation, \\ Massachusetts,USA).
}

\section{Results and Discussion}

\section{Visualization of PHA accumulation}

PHB29 bacterial colony appeared dark blue in colour and the Escherichia coli (negative control) colony remained colourless (Fig. 1A). Sudan Black B is a lipophilic dye which binds with polyesters accumulated inside the cells resulting in the dark blue stained colony morphology and E. coli colony remained colourless as it is not a natural PHA producer. The culture smear, when stained with Sudan Black B, the bacterial cells showed dark blue coloured granules in the cytoplasm, almost filled in the cells (Fig. 1B). Earlier reports also mentioned similar observations in PHBproducing bacteria (López-Cortés et al., 2008; Sathiyanarayanan et al., 2013). Nile red stained cells showed numerous bright orange-red granules within the cells under fluorescence at an excitation wavelength of $561 \mathrm{~nm}$ indicating the accumulation of PHA (Fig.1C).

\section{PHA production from starch}

When PHB29 was grown in starch containing medium, cell mass production and polymer accumulation were found to be increasing with increase in temperature, with a maximum cell dry mass (CDM) value of $3.07 \mathrm{~g} / \mathrm{L}$ and a PHA yield of $73.46 \%(\mathrm{w} / \mathrm{w})$ at $34^{\circ} \mathrm{C}$ and beyond this temperature, cell mass production as well as the polymer yield showed a decreasing trend (Fig. 2). From this, it is evident that this $B$. megaterium strain isolated from the forest soil has an optimum temperature for growth and polymer accumulation around $34{ }^{\circ} \mathrm{C}$. This yield is much higher than earlier 
reports of PHB production from $B$. megaterium using sago starch and cassava starch (Krueger et al., 2012; Yanti et al., 2013). The polymer production attained a much better level than the earlier reports from other Bacillus spp., using starch feed stocks such as raw potato starch $(34.68 \%$ w/w), hydrolyzed cassava starch $(29.7 \%$ $\mathrm{w} / \mathrm{w})$ and hydrolyzed jackfruit seed powder $(29.32 \% \mathrm{w} / \mathrm{w})$ (Krueger et al., 2012; Ali and Jamil 2014; Gowda and Shivakumar 2014).

Fig.1 A-Sudan Black B colony staining, B \& C- Polymer accumulated PHB29 cells (B-Sudan Black, C- Nile Red)
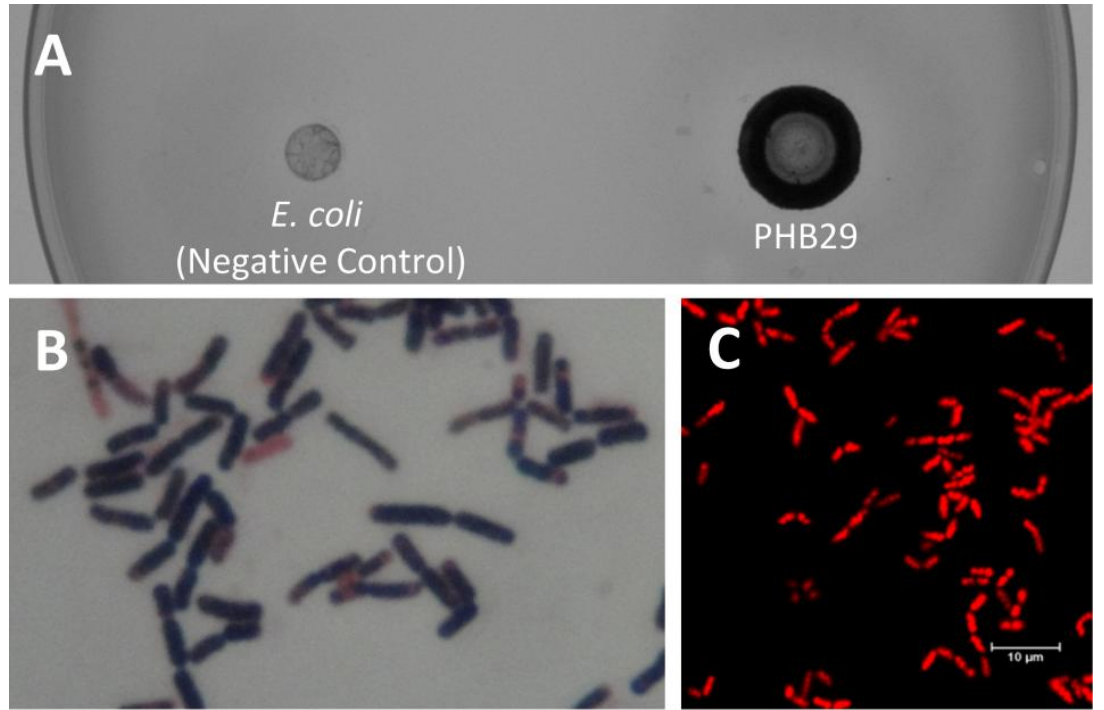

Fig.2 Growth and polymer production by PHB29 using starch as carbon feed stock at different temperatures

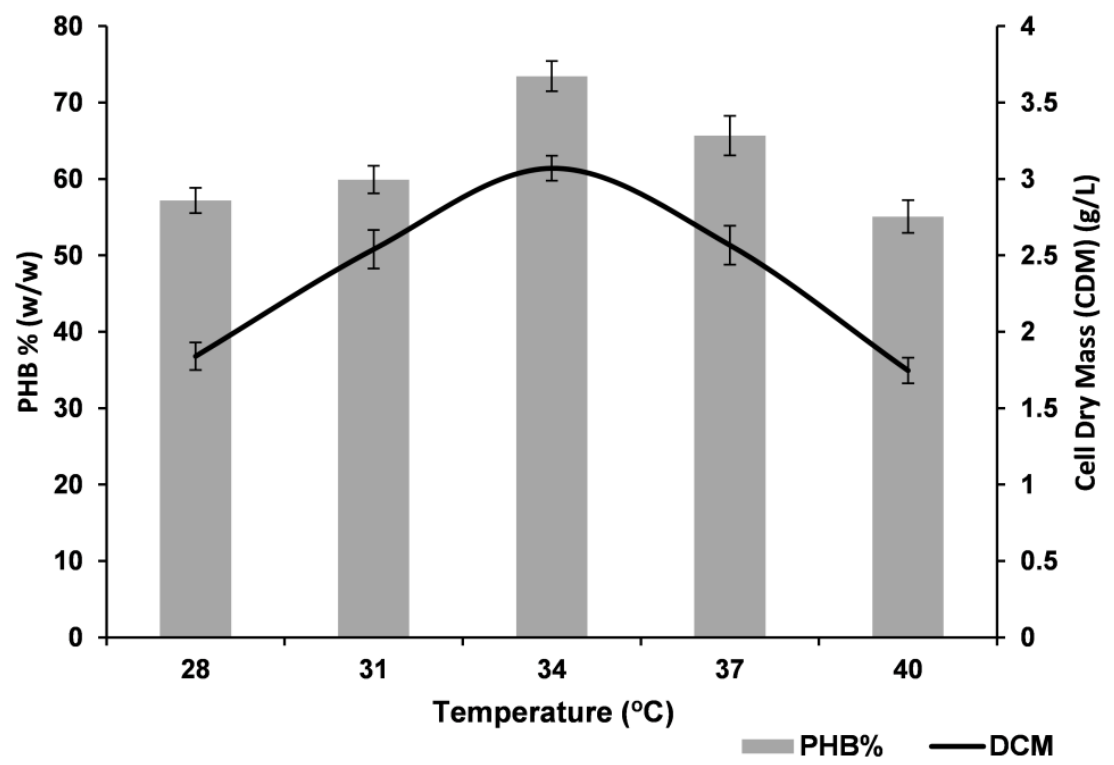


Fig.3 H NMR spectra of PHB (A-polymer standard, B-polymer extracted from PHB29)

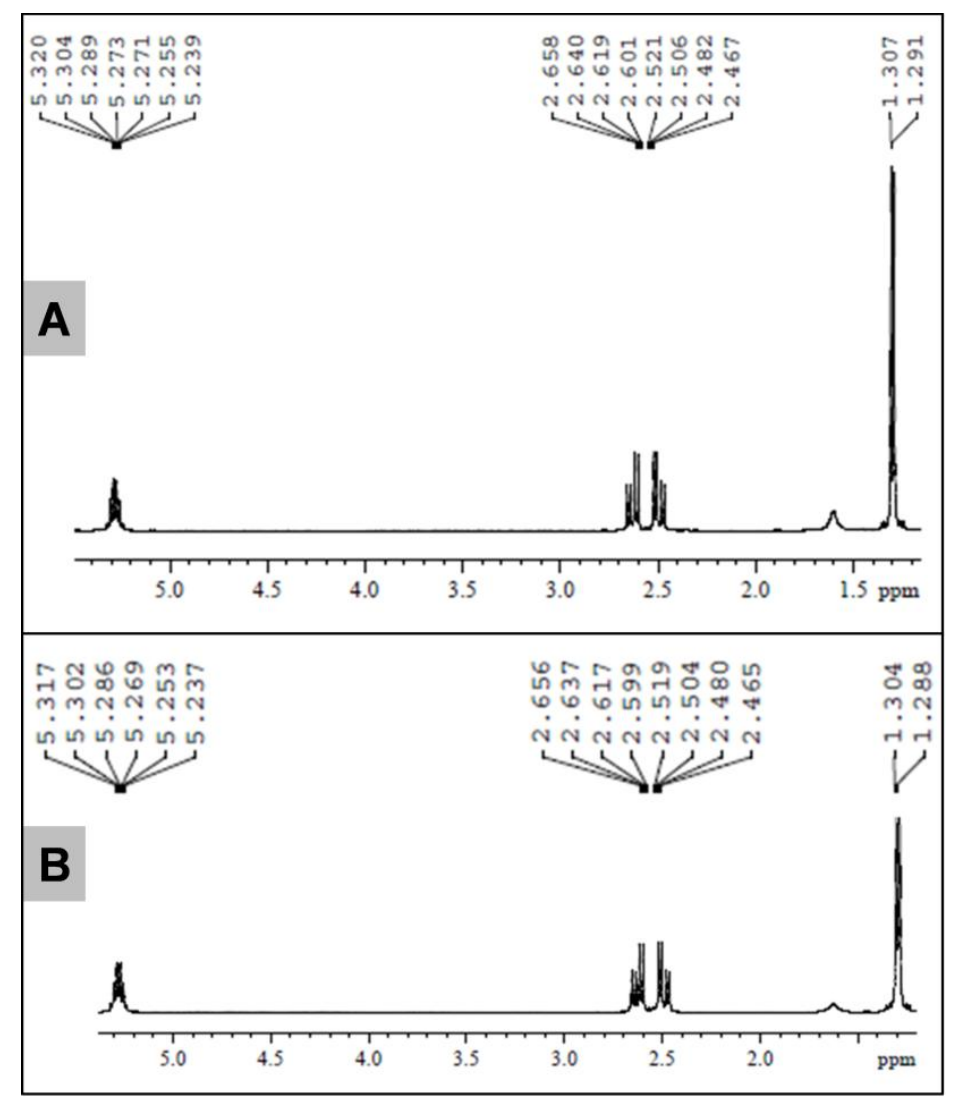

Utilising renewable and cheap carbon sources for PHA production is an ideal strategy for economical production of biodegradable plastics. Starch is a cheaper carbon source when compared to glucose and other refined carbon compounds. The higher efficiency of B. megaterium PHB29 to convert starch to PHB indicates that the bacterium possess a better amylolytic machinery working in tandem with PHB biosynthetic enzymes.

\section{Identification of the polymer}

Figure 3 shows the ${ }^{1} \mathrm{H}$ NMR spectrum of standard PHB (Sigma-Aldrich) as well as the polymer extracted from PHB29. It showed signals for a methine group (-CH-) between 5.23 and $5.32 \mathrm{ppm}$, a methylene group $\left(-\mathrm{CH}_{2}-\right)$ between 2.46 and $2.65 \mathrm{ppm}$, and the methyl group $\left(-\mathrm{CH}_{3}\right)$ between 1.28 and $1.30 \mathrm{ppm}$. These signals confirm the material as a homopolymer, Poly-3hydroxybutyrate (PHB) (Salgaonkar et al., 2013). It was previously reported that $B$. megaterium genome harbors Class IV PHA synthase gene which preferentially catalyzes the biosynthesis of short chain length PHAs such as PHB (McCool and Cannon, 2001).

In conclusion, soil bacteria are a rich source of highly efficient and novel enzymes with wide array of applications. B. megaterium PHB29 which was originally isolated from soil has efficient amylases along with PHB biosynthetic enzymes, which reflected in its superior starch to PHB conversion capacity than other reported Bacillus spp. Carbon sources contribute a major share in the production cost of PHAs and using inexpensive raw material such as starch 
instead of glucose and other refined sugars is a good option for the cost effective production of PHAs. Starch based raw materials require a prior saccharification for effective bacterial fermentation. Employing PHA producers with good amylolytic activity can circumvent this pretreatment process of the substrate and thereby aid in the reduction of the production cost. Considering all these facts the bacterial strain described in the study is an ideal candidate for the cost effective, large scale production of PHB using starch as feed stock.

\section{Acknowledgements}

The authors are grateful to Prof. M. Radhakrishna Pillai, Director, RGCB for the facilities provided. This work was supported by Department of Biotechnology, Govt. of India. Aneesh B would like to acknowledge Council of Scientific and Industrial Research (CSIR), India for awarding research fellowship (SRF; 09/716(0149)/2012-EMR-I). The authors have no conflict of interest to declare.

\section{References}

Ali, I., Jamil, N. 2014. Enhanced biosynthesis of poly (3hydroxybutyrate) from potato starch by Bacillus cereus strain 64-INS in a laboratory-scale fermenter. Prep. Biochem. Biotechnol., 44(8): 822-833.

Arjun, J.K., Aneesh, B.P., Harikrishnan, K. 2015. Sequencing and characterization of L-asparaginase (ansB) gene of Bacillus megaterium isolated from Western Ghats, Kerala, India. Int. J. Curr. Microbiol. App. Sci., 4(6): 753-760.

Braunegg, G,. Lefebvre, G., Genser, K.F. 1998. Polyhydroxyalkanoates, biopolyesters from renewable resources: physiological and engineering aspects. J. Biotechnol., 65(2):127-161.

Chen, G.Q. 2010. Plastics completely synthesized by bacteria: polyhydroxyalkanoates. In: Chen G-Q (ed) Plastics from bacteria Natural Functions and Applications. Springer Berlin Heidelberg, pp 17-37.

Chien, C.C., Ho, L.Y. 2008. Polyhydroxyalkanoates production from carbohydrates by a genetic recombinant Aeromonas sp. Lett. Appl. Microbiol., 47(6): 587-593.

Dawes, E.A., Senior, P.J. 1972. The role and regulation of energy reserve polymers in micro-organisms. Adv. Microb. Physiol., 10: 135-266.

Du, C., Sabirova, J., Soetaert, W. et al. 2012. Polyhydroxyalkanoates production from low-cost sustainable raw materials. Curr. Chem. Biol., 6(1):14-25.

Gowda, V., Shivakumar, S. 2014. Agrowaste-based

Polyhydroxyalkanoate production using hydrolytic potential of Bacillus thuringiensis IAM 12077. Braz. Arch. Biol. Technol., 57(1): 5561.

Greenspan, P., Mayer, E.P., Fowler, S.D. 1985. Nile red: a selective fluorescent stain for intracellular lipid droplets. $J$. Cell Biol., 100(3): 965-973.

Jendrossek, D., Selchow, O., Hoppert, M. 2007. Poly (3-hydroxybutyrate) granules at the early stages of formation are localized close to the cytoplasmic membrane in Caryophanon latum. Appl. Environ. Microbiol., 73(2): 586-593.

Keshavarz, T., Roy, I. 2010. Polyhydroxyalkanoates: bioplastics with a green agenda. Curr. Opin. Microbiol., 13(3): 321-326. 
Krueger, C.L., Radetski, C.M., Bendia, A.G. et al. 2012. Bioconversion of cassava starch by-product into Bacillus and related bacteria polyhydroxyalkanoates. Electron J. Biotechnol., 15(3): 8-8.

Łabużek, S., Radecka, I. 2001. Biosynthesis of PHB tercopolymer by Bacillus cereus UW85. J. Appl. Microbiol., 90(3): 353-357.

Lee, S.Y., Choi, J.i., Wong, H.H. 1999. Recent advances in polyhydroxyalkanoate production by bacterial fermentation: mini-review. Int. J. Biol. Macromol., 25(1): 31-36.

Leong, Y.K., Show, P.L., Ooi, C.W. et al. 2014 Current trends in polyhydroxyalkanoates (PHAs) biosynthesis: insights from the recombinant Escherichia coli. J. Biotechnol., 180: 52-65.

Liu, M., González, J.E,. Willis, L.B. et al. 1998. A novel screening method for isolating exopolysaccharide-deficient mutants. Appl. Environ. Microbiol., 64(11): 4600-4602.

López-Cortés, A., Lanz-Landázuri, A., García-Maldonado, J.Q. 2008. Screening and Isolation of PHBProducing Bacteria in a Polluted Marine Microbial Mat. Microb Ecol 56 (1):112-120. doi:10.1007/s00248007-9329-8

López NI, Floccari ME, Steinbüchel A et al (1995) Effect of poly (3hydroxybutyrate)(PHB) content on the starvation-survival of bacteria in natural waters. FEMS Microbiol. Ecol., 16(2): 95-101.

Madison, L.L., Huisman, G.W. 1999. Metabolic engineering of poly (3hydroxyalkanoates): from DNA to plastic. Microbiol. Mol. Biol. Rev., 63(1): 21-53.

McCool, G.J., Cannon, M.C. 2001. PhaC and $\mathrm{PhaR}$ are required for polyhydroxyalkanoic acid synthase activity in Bacillus megaterium. J. Bacteriol., 183(14): 4235-4243.

Mizuno, K., Ohta, A., Hyakutake, M. et al. $2010 . \quad$ Isolation of polyhydroxyalkanoate-producing bacteria from a polluted soil and characterization of the isolated strain Bacillus cereus YB-4. Polym. Degradation Stab., 95(8): 1335-1339.

Murray, R., Doetsch, R.N., Robinow, C. 1994. Determinative and cytological light microscopy. Methods for general and molecular bacteriol., 1: 22-41.

Panda, B., Sharma, L., Mallick, N. 2005. Poly- $\beta$-hydroxybutyrate accumulation in Nostoc muscorum and Spirulina platensis under phosphate limitation. J. Plant Physiol., 162(12): 1376-1379. Quillaguaman, J., Hashim, S., Bento, F. et al. 2005. Poly ( $\beta$-hydroxybutyrate) production by a moderate halophile, Halomonas boliviensis LC1 using starch hydrolysate as substrate. $J$. Appl. Microbiol., 99(1): 151-157.

Ruiz, J.A., Fernández, R.O., Nikel, P.I. et al 2006. dye (arc) mutants: insights into an unexplained phenotype and its suppression by the synthesis of poly (3-hydroxybutyrate) in Escherichia coli recombinants. FEMS Microbiol. Lett., 258(1): 55-60.

Salgaonkar, B., Mani, K., Braganca, J. 2013. Characterization of polyhydroxyalkanoates accumulated by a moderately halophilic salt pan isolate Bacillus megaterium strain H16. J. Appl. Microbiol., 114(5): 1347-1356.

Sathiyanarayanan, G., Kiran, G.S., Selvin, J. et al. 2013. Optimization of polyhydroxybutyrate production by marine Bacillus megaterium MSBN04 under solid state culture. Int. J. Biol. Macromol., $\quad$ 60: 253-261. 
doi:http://dx.doi.org/10.1016/j.ijbiom ac.2013.05.031

Shamala, T., Chandrashekar, A., Vijayendra, S. et al. 2003. Identification of polyhydroxyalkanoate

(PHA)-producing Bacillus spp. using the polymerase chain reaction (PCR). J. Appl. Microbiol., 94(3): 369-374.

Shi, H., Shiraishi, M., Shimizu, K. 1997. Metabolic flux analysis for biosynthesis of poly ( $\beta$ hydroxybutyric acid) in Alcaligenes eutrophus from various carbon sources. J. Ferment Bioeng., 84(6): 579-587.

Singh, M., Patel, S.K., Kalia, V.C. 2009. Bacillus subtilis as potential producer for polyhydroxyalkanoates. Microb. Cell Fact, 8(1): 1-11. doi:10.1186/1475-2859-8-38

Yanti, N.A., Sembiring, L., Margino, S. 2013. Production of Poly- $\alpha$ hydroxybutyrate (PHB) from Sago Starch by The Native Isolate Bacillus megaterium PSA10. Indones $J$. Biotechnol., 14(1): 1111-1116.

\section{How to cite this article:}

Balakrishna Pillai Aneesh, Jaya Kumar Arjun, Thulasi Kavitha and Kumarapillai Harikrishnan. 2016. Production of Short Chain Length Polyhydroxyalkanoates by Bacillus megaterium PHB29 from Starch Feed Stock. Int.J.Curr.Microbiol.App.Sci. 5(7): 816-823. doi: http://dx.doi.org/10.20546/ijcmas.2016.507.094 